\title{
Keterkaitan Kota Demak terhadap Kota Semarang dalam Lingkup Wilayah Metropolitan
}

\author{
Triani Agustina Rahayu ${ }^{1}$ \\ PT Jakarta Konsultindo \\ DKI Jakarta, Indonesia
}

\begin{abstract}
Abstrak: Penggunaan ruang untuk populasi dengan konsentrasi aktivitas yang besar ada di kota-kota besar seperti wilayah metropolitan. Proses urbanisasi yang terjadi pada kota-kota tersebut berlangsung secara dinamis dan bahkan cenderung meningkat. Wilayah metropolitan paling tidak terdiri dari satu kota utama dan beberapa kota satelit. Kota-kota yang bergabung tersebut cenderung berinteraksi satu sama lain, terutama antara kota satelit dengan kota induknya. Interaksi yang terjadi sangat menarik untuk dikaji lebih dalam sehingga hal tersebut menjadi topik dari penelitian ini. Kota Demak sebagai kota satelit di Provinsi Jawa Tengah memiliki keterhubungan dengan Kota Semarang yang memiliki hirarki di atasnya. Daya tarik dari kota induk tersebut menyebabkan banyak masyarakat yang lebih tertarik beraktivitas di Kota Semarang daripada di Demak. Dengan menggunakan pendekatan kuantitatif dan teknik analisis kuantitatif statistik deskriptif dan analisis crosstab, penelitian ini bertujuan untuk menentukan bentuk interaksi Kota Demak ke Kota Semarang. Berdasarkan hasil yang didapatkan, bentuk interaksi fisik Kota Demak ke Semarang membangun suatu ketergantungan karena keberadaan Semarang yang mempengaruhi bidang transportasi yang terhubung oleh jalur pergerakan utama Provinsi Jawa Tengah. Bentuk interaksi ekonomi juga cukup bergantung karena kebutuhan fasilitas penduduk Demak yang terpenuhi di Semarang. Bentuk interaksi sosial dapat dilihat dari terbentuknya keterikatan sosial antar populasi.
\end{abstract}

Kata kunci: bentuk, interaksi, metropolitan

\begin{abstract}
The use of space for the population at large concentration of activities located at large cities such as metropolitan regions. The process of urbanization that occurred in those cities takes place dynamically and even showed an increasing trend. Metropolitan regions consists of at least one main city and several satellite city in it. Incorporated cities within the metropolitan region tend to interact among each other, especially between the satellite city with its main city. The interaction between the satellite cities and main city is very interesting to study more deeply that it was appointed as the topic of this research. Demak city as one of the satellite city in the Province of Central Java has a relationship with a city that has a higher hierarchy, Semarang City. The appeal of the main city cause the population more interested in physical activities at Semarang City than at Demak City. By using quantitative approaches and techniques of quantitative analysis descriptive statistics and cross tabulation analysis, this study aims to determine the form of interaction on the Demak City to Semarang City. Based on these results, the form of physical interaction of the city of Demak to Semarang establish a dependency, because the existence of Semarang influence in the field of transport, given the two cities are connected by a path which is the main route for Central Java Regional movement so if the physical condition of the City Semarang is not possible to go through then it can not happen the movement from Demak. Forms of economic interaction of the city
\end{abstract}

\footnotetext{
${ }^{1}$ Korespondensi Penulis: PT Jakarta Konsultindo, DKI Jakarta

Email: trianiagustina.r@gmail.com
} 
is a dependency, because it occurs only in one direction from Demak especially at urban facilities, movement residents of Demak City to Semarang city to access the urban facilities that are not available in Demak, so in the field of urban facilities Demak City still depends on Semarang City. Forms of social interaction from the city of Semarang Demak against linkage, namely the relationship which is independent, the population affects the population in the city of Semarang Demak in the occurrence of social linkages.

Keywords: form, interaction, metropolitan

\section{Pendahuluan}

Pola interaksi yang terjadi antarwilayah tidak hanya terbatas pada faktor ekonomi saja tetapi lebih dari itu pola interaksi berlangsung dalam seluruh aspek kehidupan. Selain itu, interaksi antarwilayah akan memunculkan gerakan penduduk dari kedua tempat sebagai bentuk nyatanya. Pola pergerakan penduduk dari desa ke kota atau sebaliknya dapat dengan mudah dipelajari melalui pendekatan keilmuan geogafi karena pada dasarnya, pergerakan manusia tidak akan pernah lepas dari aspek keruangan yang di dalamnya terkandung berbagai unsur baik unsur fisik, sosial, ekonomi, dan budaya.

Kecenderungan perpindahan penduduk menyebabkan daerah perkotaan yang semakin meluas karena penduduk mulai mengekspansi daerah pinggiran perkotaan sebagai preferensi tempat tinggal dengan alasan harga lahan yang masih terjangkau dibandingkan di daerah pusat perkotaan. Hal tersebut menimbulkan terbentuknya kawasan dengan fungsi baru yang berperan sebagai daerah sub urbanisasi sebagai bentuk pengembangan dari pusat kota terdekatnya. Sebagai sebuah kota dengan pengembangan baru, kawasan sub urbanisasi dan kota satelit masih memiliki ketergantungan dengan kota induk berupa pelayanan infrastruktur serta sektor mata pencaharian.

Metropolitan Semarang merupakan salah satu wilayah metropolitan yang terdapat di Indonesia. Kota Semarang sebagai Ibukota Provinsi Jawa Tengah berperan sebagai kota induk dalam wilayah metropolitan Semarang. Kota Semarang mengalami perkembangan yang cukup pesat dari tahun ke tahunnya, baik dari segi pembangunan fisik maupun dari jumlah pertambahan penduduknya. Perkembangan yang terjadi pada Kota Semarang pada umumnya meyebar ke wilayah pinggirannya, yaitu Kabupaten Kendal, Kabupaten Semarang dan Kabupaten Demak. Perluasan kawasan perkotaan di Kota Semarang membentuk suatu wilayah pengembangan yang terdiri atas Kendal, Demak, Ungaran, Semarang, Purwodadi yang lebih sering dikenal sebagai wilayah Kedungsepur.

Penduduk dari Kota Demak cenderung memilih pergi ke Semarang untuk mengakses fasilitas perkotaan, terutama untuk kegiatan pendidikan, kesehatan serta perdagangan dan jasa (Suprapto, 2003: 110). Hubungan ketergantungan dari Kota Demak terhadap Kota Semarang tersebut belum tentu terjadi karena pada kenyataannya suatu kota satelit memungkinkan mampu menyediakan segala kebutuhan masyarakatnya sehingga masyarakat dari kota satelit tersebut tidak perlu bergantung kepada kota lain karena segala kebutuhannya telah dapat dipenuhi di dalam kota satelit tersebut. Oleh karena itu diperlukan suatu usaha eksplorasi yang lebih dalam untuk menganalisis pola interaksi yang terjadi antara Kota Demak dan Kota Semarang. Hubungan tersebut terutama ditinjau dari Kota Demak, karena dalam konteksnya Kota Demak yang memiliki kecenderungan untuk memiliki ketergantungan terhadap Kota Semarang.

Tujuan penelitian ini adalah untuk mengetahui bentuk hubungan keterkaitan Kota Demak terhadap Kota Semarang dalam lingkup wilayah metropolitan. Dalam kasus tersebut Kota Demak berperan sebagai kota satelit, sedangkan Kota Semarang berperan sebagai kota induknya. Adapun sasaran yang dilakukan untuk mencapai tujuan tersebut yaitu menganalisis keterkaitan fisik, yang membahas mengenai kondisi fisik yang 
menghubungkan Kota Demak dan Kota Semarang, menganalisis keterkaitan ekonomi, terdiri atas aspek mata pencaharian penduduk, lokasi belanja dan kebutuhan terhadap fasilitas perkotaan sehingga berpotensi meningkatkan pergerakan penduduk Kota Demak menuju Kota Semarang. Hal yang terakhir adalah menganalisis keterkaitan sosial yang terjadi antara masyarakat Kota Demak dengan masyarakat Kota Semarang dilihat dari segi pola kunjungan keluarga, kekerabatan dan organisasi sosial. Seperti halnya keterkaitan ekonomi, keterkaitan sosial pun berpotensi meningkatkan pergerakan penduduk Kota Demak menuju Kota Semarang.

\section{Kajian Literatur}

\section{Fenomena Urbanisasi dan Megapolitanisasi}

Urbanisasi dan megapolitanisasi pada dasarnya mengacu pada perkembangan perkotaan. Urbanisasi merupakan proses perubahan sifat kedesaan menjadi kekotaan, sedangkan megapolitanisasi adalah bergabungnya beberapa wilayah yang secara spasial telah bersifat kekotaan, yang merupakan tahapan lanjut dari urbanisasi. Secara garis besar urbanisasi terdiri atas:

a. Urbanisasi Fisiko-Spasial, perubahan ekspresi spasial suatu daerah secara fisik, yang didasarkan pada konsep morfologi kekotaan (Yunus, 2006: 10).

b. Urbanisasi Non-fisiko Spasial merupakan infiltrasi nilai-nilai kekotaan ke dalam sistem kehidupan yang terdapat di daerah perdesaan meliputi keseluruhan dimensi kehidupan manusia yaitu perilaku ekonomi, sosial, budaya, politik dan teknologi (Russwurm, dalam Yunus, 2006: 51).

Megapolitanisasi adalah bergabungnya beberapa wilayah yang secara spasial telah bersifat kekotaan, yang merupakan tahapan lanjut dari urbanisasi. Menurut Friedman (dalam Yunus, 2006: 40) terdapat empat tahapan proses keruangan kota untuk menjadi kota megapolis, yaitu:

I. Tahap terbentuknya kota-kota lokal yang berdiri sendiri

II. Tahap terjadinya dominasi kota dalam

III. Perekonomian regional terhadap kota-kota lain

IV. Tahapan penggabungan antara kota-kota dominan (primate city) dengan kota-kota yang lebih kecil dalam cakupan wilayah

V. Tahapan penggabungan kota-kota dominan menjadi suatu sistem kekotaan yang amat sangat besar

\section{Sub-urbanisasi dan Kota Satelit}

Perbedaan yang mendasar antara kota satelit dan kota sub-urbanisasi adalah dari segi fungsi kota tersebut untuk penduduknya. Sub-urbanisasi merupakan permukiman kekotaan yang hanya dimanfaatkan hanya untuk tidur di malam hari bagi penduduk yang bekerja di kota terdekat pada siang hari, sedangkan kota satelit merupakan bentuk permukiman kekotaan yang tidak hanya digunakan untuk tidur, tapi juga mampu berkontribusi terhadap pengembangan wilayah dalam bentuk komoditas, jasa dan informasi. Dilihat dari aspek ekonomi dan sosial, kota satelit mempunyai kemampuan yang memadai untuk memenuhi pekerjaan untuk penduduknya dan juga mungkin bagi penduduk di daerah sub-urbanisasi. Sementara itu, sub-urbanisasi hanya berperan sebagai penerima komoditas dan sebagai pemasok tenaga kerja baik ke kota besar maupun ke kota satelit. 


\section{Kota Metropolitan sebagai Kota Induk}

Wilayah metropolitan dapat diartikan sebagai kawasan permukiman berskala besar yang terdiri dari satu atau lebih kota besar dan kawasan yang secara keseluruhan terintegrasi, membentuk suatu sistem struktur ruang tertentu dengan satu atau lebih kota besar sebagai pusat (kota inti) dan beberapa kota lebih kecil yang berfungsi sebagai kota satelit, yang memiliki keterkaitan ekonomi dan sosial, dan mempunyai ekonomi jasa dan industri yang beragam (Winarsi, 2006: 17). Wilayah metropolitan memiliki ciri-ciri sebagai berikut (Winarsi, 2006: 20).

\section{Permasalahan yang Dihadapi oleh Wilayah Metropolitan}

Persoalan yang terjadi di wilayah metropolitan pada dasarnya dilatarbelakangi oleh pesatnya pertumbuhan kota-kota tersebut di luar antisipasi yang telah diperkirakan sebelumnya oleh para perencana kota. Hal tersebut dikarenakan oleh terjadinya penumpukan jumlah penduduk yang terkonsentrasi di wilayah metropolitan sehingga terjadi penumpukan modal, fungsi pelayanan sarana prasarana perkotaan serta permasalahan yang lainnya yang menjadi semakin kompleks karena melibatkan beberapa sektor kehidupan. Permasalahan yang dihadapi oleh wilayah metropolitan akan mempunyai karakteristik skala yang besar, keterkaitan antar sektor yang kompleks dan tingkat kesulitan pemecahan permasalahan yang sangat tinggi (Winarsi, 2006: 105).

\section{Interaksi Antarkota}

Menurut Yunus (2010: 64) interaksi atau dengan kata lain dapat dikatakan imbal daya, merupakan suatu proses yang saling mempengaruhi antara dua hal. Jika interaksi tersebut dihubungkan dengan ruang, maka proses saling mempengaruhi yang terjadi pun antar ruang. Menurut pendapat Ullman (dalam Yunus, 2010: 64), interaksi spasial menekankan pada terjadinya ketergantungan di antara beberapa area dan berimplikasi pada terjadinya perpindahan komoditas, barang, manusia dan lain-lain di antara beberapa daerah. Wujud dari hubungan atau interaksi yang terjadi antar kota atau antar wilayah dapat diwujudkan melalui urbanisasi, ruralisasi, sirkulasi serta ulang-alik (commuting). Pada kenyataannya bentuk interaksi antar daerah sangat bervariasi, yang jika disimulasikan oleh kota A dan Kota B terdiri atas (Yunus, 2010: 65):

- Interaksi seimbang (balanced interaction), A dan B saling mempengaruhi tetapi tidak tergantung satu sama lain.

- Interaksi yang tidak seimbang (imbalanced interaction), A mempengaruhi B namun tidak tergantung pada $\mathrm{B}$, tapi $\mathrm{B}$ tergantung pada $\mathrm{A}$.

- A dan B saling tergantung (interdependency).

Menurut Rustiadi (2009: 49), spasial dapat dipandang dari segi geografi dan segi sosial-ekonomi. Berdasarkan persfektif geografi, spasial merupakan segala hal yang berhubungan dengan tempat atau lokasi. Definisi dari tempat itu sangat terukur, jelas dan dapat diukur secara kuantiatif karena lokasi terdapat di atas permukaan bumi. Sementara itu jika dipandang dari perspektif sosial-ekonomi, ruang tidak dititikberatkan pada lokasi atau tempat secara kuantitatif, tapi lebih ditekankan pada permasalahannya, apa yang menjadi masalah dan mengapa permasalahan itu terjadi. 
Tabel 1. Jenis Keterkaitan Spasial Menurut Rondinelli

\begin{tabular}{|c|c|}
\hline Tipe & Elemen-elemen \\
\hline \multirow{4}{*}{ Keterkaitan fisik } & Jaringan jalan \\
\hline & Jaringan transportasi sungai dan air \\
\hline & Jaringan kereta api \\
\hline & Ketergantungan ekologis \\
\hline \multirow{6}{*}{ Keterkaitan ekonomi } & Pola-pola pasar \\
\hline & Arus bahan baku dan barang antara \\
\hline & Arus modal, keterkaitan produksi \\
\hline & Pola konsumsi dan belanja \\
\hline & Arus pendapatan \\
\hline & $\begin{array}{l}\text { Arus komoditi sektoral dan } \\
\text { interregional cross linkages }\end{array}$ \\
\hline \multirow{2}{*}{$\begin{array}{l}\text { Keterkaitan } \\
\text { berupa mobilitas penduduk }\end{array}$} & Migrasi \\
\hline & Perjalanan kerja \\
\hline \multirow{4}{*}{ Keterkaitan interaksi sosial } & Pola visiting \\
\hline & Pola kinship \\
\hline & $\begin{array}{l}\text { Kegiatan rites, ritual dan } \\
\text { keagamaan }\end{array}$ \\
\hline & Interaksi kelompok sosial \\
\hline \multirow{6}{*}{ Keterkaitan delivery pelayanan } & Arus dan jaringan energi \\
\hline & Jaringan kredit dan finansial \\
\hline & $\begin{array}{l}\text { Keterkaitan pendidikan, training dan } \\
\text { pengembangan }\end{array}$ \\
\hline & Sistem delivery pelayanan kesehatan \\
\hline & $\begin{array}{l}\text { Pola pelayanan profesional, } \\
\text { komersial dan teknik }\end{array}$ \\
\hline & Sistem pelayanan transportasi \\
\hline \multirow{6}{*}{$\begin{array}{l}\text { Keterkaitan politik, administrasi dan } \\
\text { organisasi }\end{array}$} & Hubungan structural \\
\hline & Arus budget pemerintah \\
\hline & Kebergantungan organisasi \\
\hline & Pola otoritas approval supervisi \\
\hline & Pola transaksi inter yuridiksi \\
\hline & Rantai keputusan politik formal \\
\hline
\end{tabular}

Sumber: Rondinelli, 1985: 143

\section{Variabel Penelitian}

Berdasarkan teori di atas, variabel dalam penelitian ini terdiri atas:

- Keterkaitan fisik merupakan kondisi fisik yang menghubungkan Kota Demak dengan Kota Semarang, yang dilihat berdasarkan kondisi jaringan jalan, biaya transportasi, waktu tempuh, moda transportasi dan tingkat hambatan.

- Keterkaitan ekonomi dilatarbelakangi motif ekonomi berupa upaya masyarakat untuk memenuhi kebutuhannya, yang dapat terjadi akibat perbedaan sumber daya yang dimiliki Kota Demak dan Kota Semarang. 
- Hubungan sosial dapat mencerminkan sejauh mana masyarakat memandang suatu area sebagai suatu kesatuan dari beberapa unit kehidupan sosial yang dilihat dari hubungan kekeluargaan, hubungan kekerabatan dan organisasi sosial.

\section{Metode Penelitian}

Penelitian berkaitan dengan tiga aspek utama, yaitu eksistensi populasi, karakteristik objek penelitian dan metode yang digunakan dalam menganalisis data. Penelitian ini berangkat dari adanya fenomena mengenai interaksi antara Kota Demak terhadap Kota Semarang, yang kemudian diterjemahkan menjadi interaksi antar wilayah antara kota satelit terhadap kota induknya dalam lingkup wilayah metropolitan. Beberapa kota satelit belum mampu memenuhi segala kebutuhan masyarakatnya sehingga masyarakat harus mengakses ke kota lain yang memiliki hirarki di atasnya. Berdasarkan fenomena tersebut, peneliti menarik hipotesis bahwa Kota Demak mengalami ketergantungan terhadap Kota Semarang, yang mencakup aspek-aspek fisik, ekonomi dan sosial. Oleh karena itu penelitian yang dilakukan menggunakan metode penelitian kuantitatif karena berbagai pertimbangan dalam teknik pelaksanaannya.

\section{Objek Penelitian}

Populasi dalam penelitian ini adalah masyarakat yang bertempat tinggal di Kota Demak tepatnya di Kelurahan Bintoro sebagai pusat Kota Kecamatan Demak yang mencerminkan kota satelit. Kriteria populasi yang akan diambil sebagai responden yaitu masyarakat di Kelurahan Bintoro yang melakukan pergerakan menuju Kota Semarang baik untuk kepentingan sosial maupun ekonomi. Kriteria-kriteria tersebut dijelaskan secara lebih rinci dalam Tabel 2.

Tabel 2. Kriteria Objek Penelitian

\begin{tabular}{|l|l|l|}
\hline No. & \multicolumn{1}{|c|}{ Kriteria Objek Penelitian } & \multicolumn{1}{c|}{ Justifikasi Pemilihan Objek } \\
\hline 1 & $\begin{array}{l}\text { Penduduk asli dan pendatang yang } \\
\text { menetap di Kelurahan Bintoro Kota } \\
\text { Demak yang melakukan pergerakan ke } \\
\text { Kota Semarang setiap harinya }\end{array}$ & $\begin{array}{l}\text { Penduduk asli dan pendatang merupakan masyarakat } \\
\text { yang mendiami di wilayah pengamatan pada penelitian } \\
\text { mengenai keterkaitan Kota Demak terhadap Kota } \\
\text { Semarang. }\end{array}$ \\
\hline 2 & Penduduk usia 15-50 tahun & $\begin{array}{l}\text { Usia tersebut merupakan kategori dimana seseorang } \\
\text { dapat dikatakan termasuk produktif dan memungkinkan } \\
\text { melakukan pergerakan menuju Kota Semarang }\end{array}$ \\
\hline
\end{tabular}

Berdasarkan karakteristik objek penelitian, penelitian ini termasuk ke dalam kriteria penelitian studi kasus, karena objek penelitian mempunyai sifat yang sangat khusus sesuai dengan yang tercantum pada Tabel 2. Hasil penelitian ini khusus hanya berlaku pada objek yang bersangkutan saja karena tujuannya tidak diinferensiakan pada populasi. Justifikasi pemilihan studi kasus dalam penelitian ini adalah dikarenakan sifat objek penelitian yang sangat khusus yang menjadi pertimbangan dalam upaya untuk eksplorasi informasi secara lebih mendalam. Metode studi kasus yang dilakukan dalam penelitian ini dengan menggunakan metode snowball (bola salju). Dengan metode ini berarti tidak semua anggota populasi mempunyai kesempatan yang sama untuk terpilih sebagai responden.

Metode snowball menuntut peneliti utuk menentukan kriteria, kemudian memilih responden yang pertama. Responden pertama tersebut akan memberikan informasi mengenai siapa yang akan menjadi responden kedua, dan seterusnya. Informasi tersebut 
juga dapat diperoleh pada tokoh masyarakat yang mengetahui secara pasti mengenai kondisi masyarakatnya. Pemilihan anggota responden akan dilakukan secara terus menerus hingga informasi yang didapatkan bersifat homogen/ jenuh. Jadi dengan kata lain dapat disimpulkan bahwa pada awalnya jumlah sampelnya sedikit namun akan semakin banyak karena jumlah sumber data yang sedikit itu belum mampu memberikan informasi yang cukup.

\section{Data Penelitian}

Data-data yang dibutuhkan dalam penelitian tentang pola pergerakan masyarakat ini sebagian besar bersumber dari pengamatan langsung (data primer). Hal ini bertujuan untuk mendapatkan data yang lebih relevan dan tentunya akan lebih menggambarkan kondisi nyata. Teknik pengumpulan data dilakukan dengan kuesioner, telaah dokumen dan observasi. Adapun teknik analisis yang digunakan yaitu teknik analisis kuantitatif dengan alat analisis statistik deskriptif dan analisis crosstab.

\section{Profil Kota Demak}

Wilayah Kedungsepur termasuk dalam wilayah kerjasama strategis dalam Provinsi yang dikembangkan secara intraregional sebagai pusat distribusi bagi produk dari daerah pedalaman karena berada sekitar jalur pantura dan secara interregional dan nasional merupakan tempat transit perdagangan dan jasa dari wilayah barat dan timur Jawa serta pulau-pulau lainnya terutama Pulau Kalimantan (RTRW Provinsi Jawa Tengah, 20102030).

Kota Semarang diklasifikasikan ke dalam kota induk karena berperan sebagai pusat pelayanan di Provinsi Jawa Tengah yang memiliki perkembangan yang sangat pesat. Terlebih Kota Semarang merupakan ibukota dari Provinsi Jawa Tengah yang merupakan pusat kegiatan perekonomian baik perdagangan, jasa maupun industri. Secara intra wilayah, Kota Semarang sangat berperan sebagai pusat distribusi produk dari daerah perdesaan. Dalam skala antarwilayah dan nasional, Kota Semarang berperan sebagai tempat transit perdagangan dan jasa baik di Pulau Jawa maupun antarpulau, yang sangat didukung oleh letaknya karena dilalui oleh Jalur Pantai Utara. Pesatnya perkembangan Kota Semarang menyebabkan terbentuknya Wilayah Metropolitan Semarang (Winarsi, 2006: 92).

Letak geografis Kota Demak berada di Kabupaten Demak bagian tengah, yang merupakan pusat pemerintahan dan perekonomian. Di samping itu dari sisi perhubungan darat, Kota Demak dilintasi oleh jalur lalu lintas yang cukup ramai yaitu jalur Pantai Utara Jawa. Kota Demak merupakan ibukota dari Kabupaten Demak, dengan luas wilayah $61,13 \mathrm{~km} 2$. Kondisi kependudukan di suatu daerah perlu diidentifikasi karena berkaitan dengan aspek sosial ekonomi. Kependudukan Kota Demak dapat dilihat pada Tabel 3.

Tabel 3. Kondisi Kependudukan Kota Demak Tahun 2009

\begin{tabular}{|c|c|r|}
\hline No. & Keterangan & Jumlah (jiwa) \\
\hline 1 & Jumlah penduduk (jiwa) & 98.483 \\
\hline 2 & Jumlah Rumah Tangga & 29.379 \\
\hline 3 & Kepadatan penduduk (jiwa/km2) & 1.611 \\
\hline 4 & Jumlah penduduk yang datang & 480 \\
\hline 5 & Jumlah penduduk yang pindah & 408 \\
\hline
\end{tabular}

Sumber: Kecamatan Demak Dalam Angka, 2009 


\section{Keterkaitan Kota Demak terhadap Kota Semarang dalam Lingkup Wilayah Metropolitan}

Penggunaan lahan paling tinggi adalah untuk penggunaan tanah kering dengan spesifikasi pekarangan/ bangunan. Lalu urutan kedua yaitu penggunaan lahan sebagai sawah teknis. Penggunaan lahan sebagai bangunan/ pekarangan lebih tinggi daripada penggunaan lahan untuk sawah. Penggunaan lahan di Kota Demak ditunjukkan oleh tabel berikut.

Tabel 4. Penggunaan Lahan di Kota Demak Tahun 2009

\begin{tabular}{|c|c|}
\hline Fungsi lahan & Luas (Ha) \\
\hline Tanah Sawah & \\
\hline Sawah teknis & $1.029,99$ \\
\hline Tanah Kering & 860,99 \\
\hline Pekarangan/ bangunan & $1.057,00$ \\
\hline Tegalan/ Kebun & 11,50 \\
\hline Tebat/ Empang & 289,01 \\
\hline Lainnya (sungai, jalan, dll) & $2.218,50$ \\
\hline Jumlah & \\
\hline
\end{tabular}

Sumber: Kecamatan Demak Dalam Angka, 2009

\section{Temuan}

\section{Analisis Keterkaitan Fisik}

Arus sirkulasi di koridor Jalan Demak- Semarang dilalui oleh jalan utama yang merupakan jalur Pantai Utara Jawa yang berada di Provinsi Jawa Tengah memanjang dari Kota Tegal sampai Kota Rembang. Ruas Jalan Pantura yang melalui Kota Demak terdiri atas dua jalur dan empat lajur yang di dalamnya tidak terdapat pemisahan untuk kendaraan roda dua dan roda empat. Sementara itu sirkulasi di jalan utama yang terjadi di dalam Kota Demak mengalami pemisahan lajur untuk kendaraan yang memiliki roda dua dan becak dipisahkan dari lajur kendaraan roda empat. Hal tersebut membuat sirkulasi jalan terlihat lebih teratur. Meskipun pemisahan sirkulasi kendaraan tidak terjadi di seluruh jalan di Kota Demak namun hal tersebut sudah membuat arus transportasi lebih nyaman.

Berdasarkan hasil penyebaran kuesioner kepada masyarakat Kota Demak yang melakukan pergerakan menuju Kota Semarang setiap harinya, jika diminta untuk memilih, 91\% lebih memilih untuk menggunakan kendaraan pribadi karena mereka merasa akan lebih cepat dan dapat menghemat biaya transportasi jika perjalanan tersebut ditempuh dengan menggunakan sepeda motor. Namun pada kenyataannya dalam melakukan pergerakan menuju Kota Semarang, yaitu sebanyak 54\% dari jumlah responden secara keseluruhan, 32\% menggunakan bus dan 14\% menggunakan mobil pribadi.

Jika dilihat dari segi biaya transportasi, dengan menggunakan kendaraan umum, para pelajar dan pekerja yang mengenakan seragam di pabrik atau sektor industri hanya membayar ongkos Rp 2.000,- sekali perjalanan, dari harga normal Rp 3.000,-Jika ditempuh dengan menggunakan sepeda motor dalam setiap perjalanannya hanya dibutuhkan biaya bensin sekitar Rp 10.000,- bahkan masih memungkinkan untuk digunakan perjalanan pulang pergi. Lain halnya dengan menggunakan kendaraan roda empat berupa mobil pribadi, dalam sekali perjalanan bisa mencapai Rp 50.000,-. Penilaian tingkat hambatan aksesibilitas dari para responden didominasi oleh faktor cuaca $(31 \%)$ dan sulitnya memperoleh bus (31\%). Pemilihan responden yang lebih rinci disajikan dalam Gambar 1 berikut. 


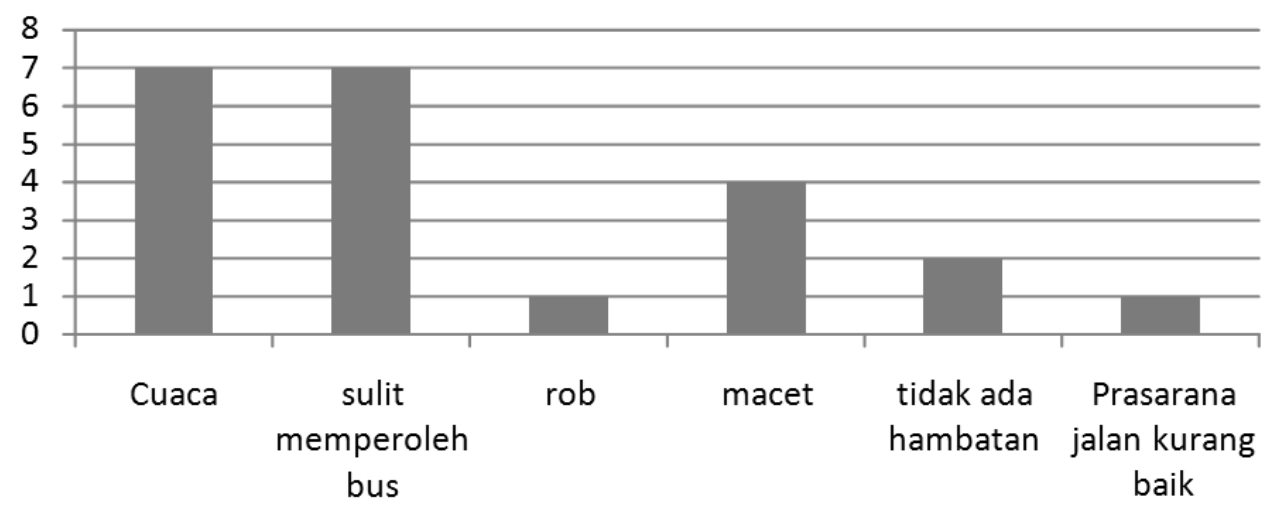

Gambar 1. Diagram Pemilihan Hambatan dari Kota Demak ke Kota Semarang

Pemilihan tingkat hambatan aksesibilitas tersebut dilatarbelakangi oleh beberapa alasan yang diterjemahkan oleh peneliti menjadi beberapa hal yang sangat berkaitan dengan faktor yang mendukung aspek kemudahan untuk menjangkau Kota Semarang dari arah Kota Demak. Faktor-faktor yang mempengaruhi tersebut terdiri atas jenis kendaraan yang digunakan, waktu tempuh, biaya transportasi dan ketersediaan transportasi umum yang melewati tempat tinggal penduduk Kota Demak.

Penentuan tingkat aksesibilitas didapat dari jawaban responden mengenai pertanyaan yang tercantum di dalam form kuesioner, yang diklasifikasikan menjadi dua kategori yaitu hambatan aksesibilitas tinggi dan hambatan aksesibilitas rendah. Tingkat hambatan aksesibilitas rendah didapat dari jawaban responden yang menyatakan bahwa hambatan tersebut tidak terlalu mengganggu mereka yang akan tetap dapat menuju Kota Semarang dari Kota Demak sedangkan hambatan aksesibilitas tinggi merupakan hambatan berupa faktor sangat vital sehingga mereka sulit untuk dapat menuju Kota Semarang. Adapun pengkasifikasian tingkat aksesibilitas dapat dilihat berdasarkan Tabel 5 berikut.

Tabel 5. Klasifikasi Tingkat Hambatan Aksesibilitas dari Kota Demak Menuju Kota Semarang

\begin{tabular}{|l|l|}
\hline Kriteria Hambatan & \multicolumn{1}{|c|}{ Jenis Hambatan } \\
\hline Rendah & Faktor cuaca yang sangat panas, tidak ada hambatan \\
\hline Tinggi & Sulit memperoleh bus, macet, perbaikan jalan, terjadi rob di Kota Semarang \\
\hline
\end{tabular}

Faktor cuaca yang sangat panas masih termasuk ke dalam klasifikasi hambatan rendah dikarenakan hambatan berupa cuaca bersifat subjektif tergantung penilaian setiap individu, kondisi cuaca panas bagi seseorang belum tentu panas bagi individu lainnya. Jadi ketika seseorang merasakan cuaca yang begitu panas belum tentu orang lain merasakan hal yang sama. Faktor yang menyebabkan tingkat aksesibilitas menjadi rendah terdiri atas sulitnya memperoleh bus, macet, perbaikan jalan dan terjadi rob di Kota Semarang. Hal-hal tersebut merupakan kondisi yang mutlak dapat mempersulit pergerakan penduduk Kota Demak untuk menuju Kota Semarang dan dapat menjadi hambatan yang menyita waktu tempuh lebih lama dibandingkan dengan kondisi yang tidak disertai oleh hal-hal seperti demikian.

Alat analisis yang digunakan yaitu analisis crosstab sehingga sebelumnya dilakukan pengelompokan terhadap variabel bebas dan variabel terikat sebagai database dalam 


\section{Keterkaitan Kota Demak terhadap Kota Semarang dalam Lingkup Wilayah Metropolitan}

pengolahan data. Berdasarkan uji signifikansi chi-square antara variabel terikat tingkat hambatan aksesibilitas dan variabel-variabel bebas yang terdiri atas kendaraan yang digunakan, waktu tempuh, biaya transportasi dan ketersediaan transportasi umum yang melewati tempat tinggal penduduk, didapatkan nilai yang paling tinggi yaitu antara tingkat hambatan aksesibilitas terhadap waktu tempuh, bernilai 0,01 yang kurang dari 0,05 berarti terdapat hubungan di antara keduanya, dengan nilai 0,548 yang berarti mempunyai hubungan yang cukup kuat karena mempunyai nilai mendekati 1.

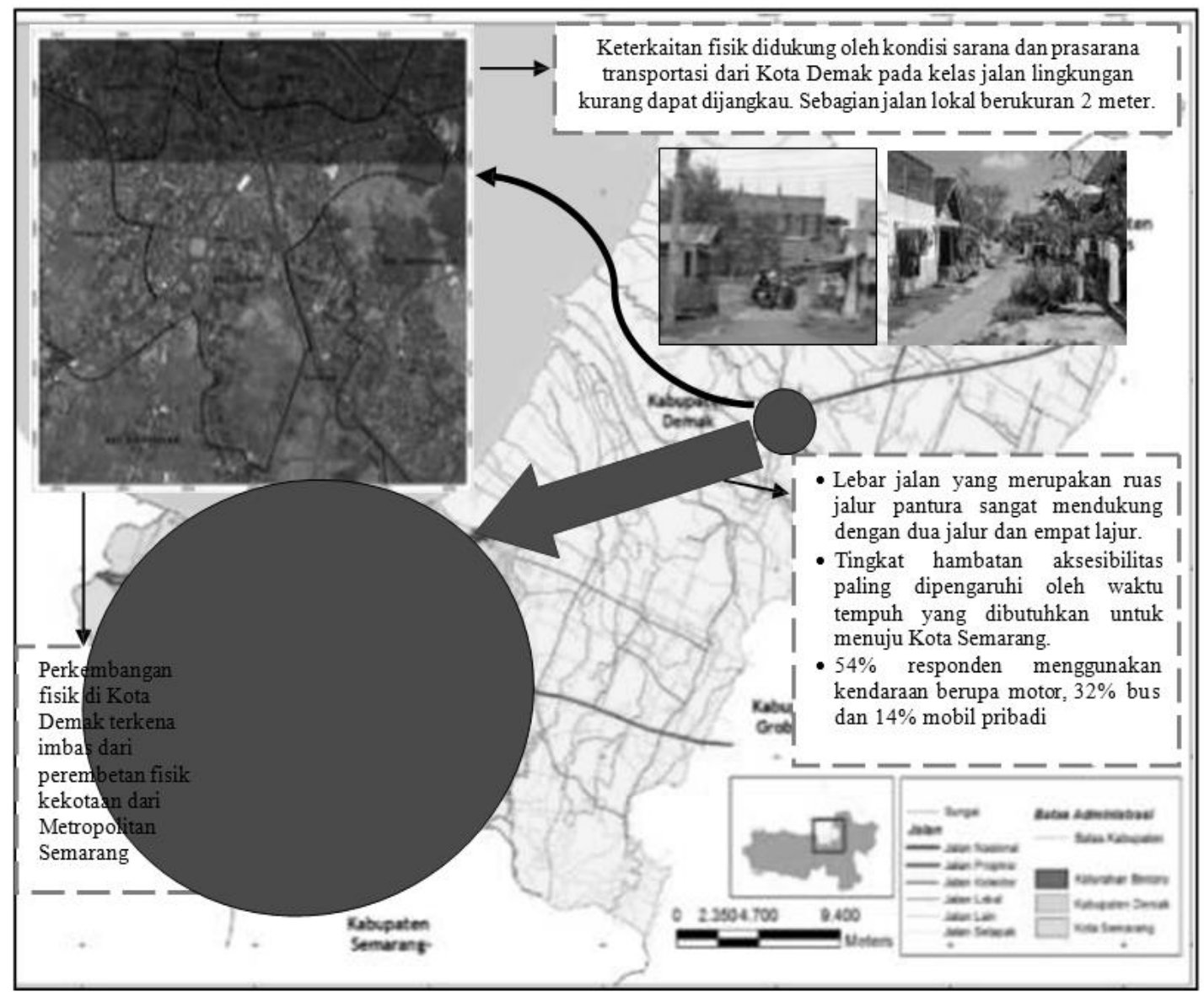

Gambar 2. Keterkaitan Fisik Kota Demak terhadap Kota Semarang

Tiga variabel bebas lainnya yang meliputi kendaraan yang digunakan, biaya transportasi dan ketersediaan transportasi umum yang melewati tempat tinggal penduduk memiliki nilai uji signifikansi chi-square lebih dari 0,05 berarti tidak terdapat hubungan diantara variabel terikat tingkat hambatan aksesibilitas dengan ketiga faktor tersebut. Analisis keterkaitan fisik dari Kota Demak terhadap Kota Semarang secara keseluruhan digambarkan dalam Gambar 2.

\section{Analisis Keterkaitan Ekonomi}

Profesi sebagai buruh tani mengalami peningkatan sekitar 80\% dari tahun 2003, sedangkan petani sendiri mengalami pengurangan hampir 50\%, bahkan perikanan berkurang sangat tajam karena pada tahun 2009 sektor tersebut sudah tidak ada lagi. Sedangkan dalam 
bidang industri mengalami kenaikan sekitar 50\% dari tahun 2003. Pesatnya peningkatan sebagai buruh tani dan penurunan sebagai petani sendiri pun tidak lepas terpengaruh dari perembetan spasial yang terjadi di Kota Demak terutama yang lahan berada di sepanjang jalan utama. Fenomena tersebut pun tidak terjadi begitu saja, terdapat tahapan yang membuat struktur mata pencaharian penduduk berubah. Yunus (2006: 14) menyatakan bahwa jumlah petani semakin berkurang secara berangsur-angsur menjadi non-petani. Hal yang terjadi di Kota Demak sesuai dengan pernyataan Yunus. Lahan pertanian semakin berkurang dikarenakan adanya tuntutan ruang yang lebih tinggi seiring dengan kompleksitas aktivitas penduduk dan pertambahan penduduk dari tahun ke tahun. Perkembangan fisik Kota Demak yang dipengaruhi oleh perkembangan Kota Semarang pun turut menjadi andil yang cukup besar dalam pergeseran struktur mata pencaharian penduduk Kota Demak.

Setiap perusahaan industri tentunya membutuhkan tenaga kerja dalam jumlah yang banyak, dan tidak semua penduduk Kota Semarang dapat memenuhi tenaga kerja dalam bidang tersebut. Oleh karena itu penduduk yang berasal dari kota-kota di sekitarnya turut mempunyai andil dalam kemajuan industri tersebut sehingga penduduk Kota Demak pun pada umumnya yang bekerja di Kota Semarang. Fenomena seperti demikian sejalan dengan teori bahwa penduduk dari perdesaan atau kota kecil tertarik untuk memasuki wilayah metropolitan dengan harapan memperoleh tingkat penghidupan yang lebih layak daripada di perdesaan atau kota yang lebih kecil (Winarsi, 2006: 108).

Hasil penyebaran kuesioner untuk para komuter yang melakukan perjalanan ke Kota Semarang menunjukkan bahwa sebanyak 99,9\% responden merasa Kota Demak masih mempunyai kekurangan fasilitas mulai dari fasilitas perekonomian, kesehatan, pendidikan dan rekreasi. Kondisi seperti itu menuntut masyarakat Demak untuk pergi ke tempat lain untuk memperoleh fasilitas yang lebih lengkap. Hasil jawaban para responden mengenai fasilitas perkotaan di Kota Demak yang dinilai kurang, dengan pilihan yang boleh lebih dari satu ditunjukkan oleh Gambar 3.

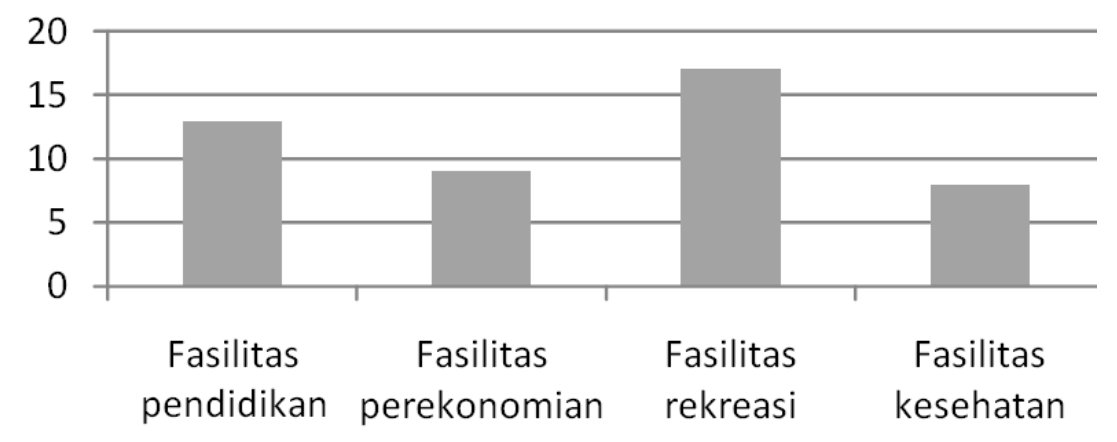

\section{Gambar 3. Grafik Fasilitas Perkotaan yang Dinilai Kurang di Kota Demak}

Berdasarkan hasil penyebaran terhadap para responden, 86\% para komuter yang berasal dari Kota Demak tersebut juga melakukan transaksi pembelian barang di Kota Semarang. Jenis barang yang dibeli oleh masyarakat Kota Demak di Kota Semarang didominasi oleh pembelian terhadap pakaian, yaitu sebanyak $37 \%$ dari jumlah keseluruhan. $\mathrm{Hal}$ tersebut berkaitan erat dengan fasilitas perekonomian yang berupa fasilitas perdagangan di Kota Semarang. Para responden yang membeli pakaian di Kota Semarang mempunyai alasan sulitnya memperoleh pakaian yang sesuai dengan selera jika membelinya di Kota Demak dan alasan lainnya adalah tidak tersedianya toko pakaian yang lengkap di Kota Demak. 


\section{Keterkaitan Kota Demak terhadap Kota Semarang dalam Lingkup Wilayah Metropolitan}

Setiap daerah menspesialisasikan barang produksinya sesuai dengan kemampuan daerah tersebut dan keuntungan produksi yang didapatkannya (Adisasmita, 2006: 150). Hal tersebut pun terjadi di Kota Demak, bahwa tidak semua barang dapat diproduksi dan dapat tersedia di Kota Demak. Kemudian cara untuk mengatasi kelangkaan barang yang dimaksud tersebut adalah dengan mendatangkan ataupun memperolehnya dari kota lain di dekatnya, yaitu Kota Semarang yang merupakan kota yang memiliki hirarki jauh lebih tinggi dibandingkan dengan Kota Demak, sehingga terjadilah hubungan interaksi antarkota. Oleh karena itu setiap kota pasti menspesialisasikan barang yang dapat melayani masyarakatnya seperti yang terjadi di Kota Demak. Hasil penyebaran kuesioner, 91\% penduduk tersebut membeli keperluan makanan sehari-hari di Kota Demak tentunya dengan frekuensi perbelanjaan setiap hari.

Ketersediaan fasilitas di Kota Demak dan Kota Semarang mempengaruhi tingkat pergerakan penduduknya sehingga mempengaruhi pula terhadap keterkaitan antara kedua kota tersebut. Setiap kota pasti memiliki fasilitas perkotaan yang berbeda-beda baik dari segi jumlah maupun ukurannya. Hal tersebut dipengaruhi oleh hirarki setiap kota karena penyediaan fasilitas perkotaan pasti disesuaikan dengan kebutuhan penduduknya. Sejalan dengan itu, Yunus (2010: 314) mengemukakan bahwa pada umumnya hirarki perkotaan akan menyebabkan tingkat pelayanan yang berbeda pula, sehingga masyarakat akan melakukan pergerakan untuk menuju kota lain untuk memperoleh komoditas yang dibutuhkannya.

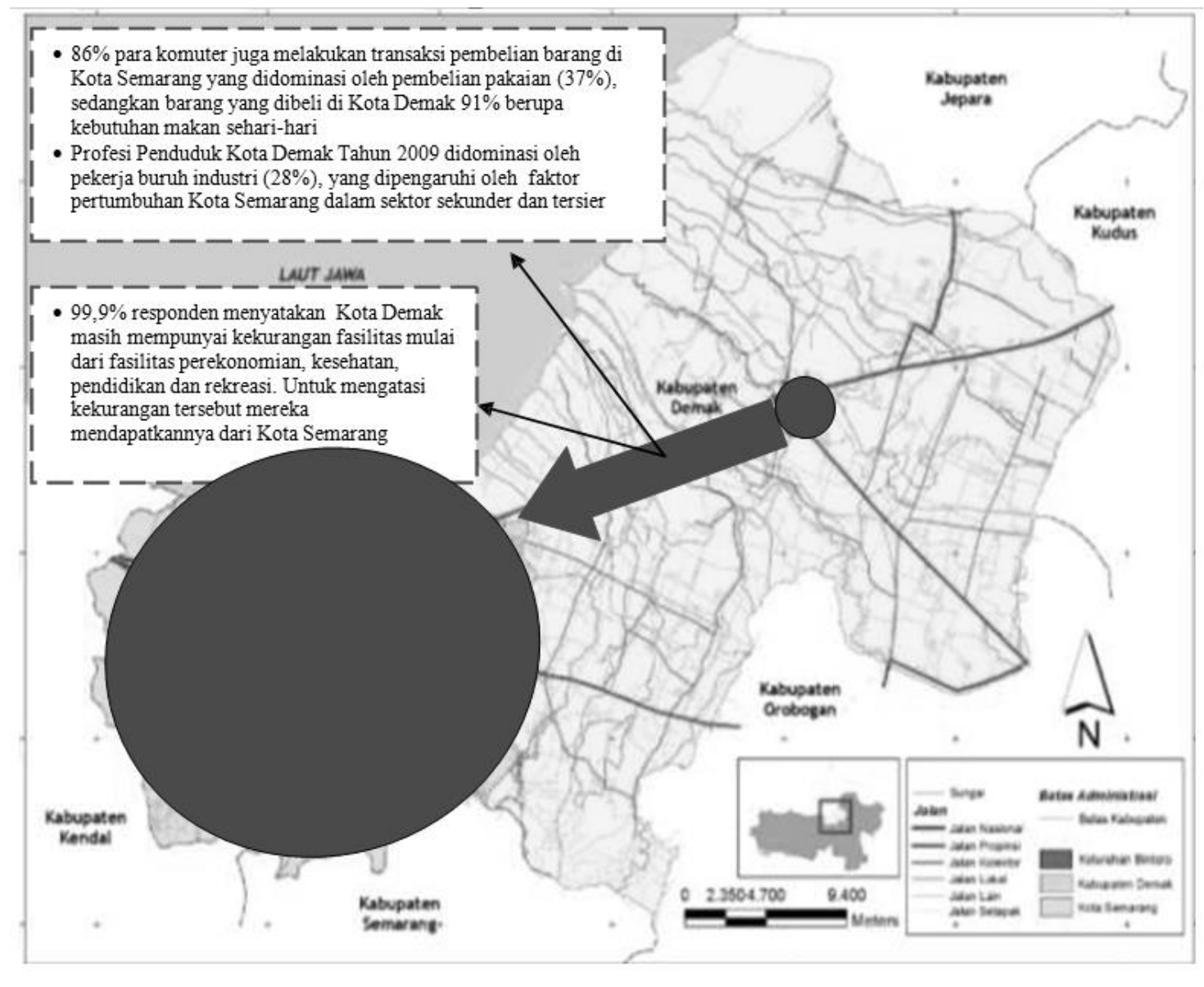

Gambar 4. Keterkaitan Ekonomi Kota Demak terhadap Kota Semarang 


\section{Analisis Keterkaitan Sosial}

Hubungan sosial yang terjadi antara masyarakat di Kota Demak memiliki kecenderungan untuk melakukan interaksi terhadap masyarakat di Kota Semarang karena sebagian besar ternyata mempunyai saudara di Kota Semarang. Berdasarkan hasil penyebaran kuesioner, $50 \%$ responden yang melakukan pergerakan menuju Kota Semarang di setiap harinya ternyata memiliki saudara yang menetap di Kota Semarang.

Untuk masyarakat Kota Demak yang memiliki hubungan teman yang menetap di Kota Semarang, berdasarkan hasil kuesioner, $100 \%$ responden memiliki teman yang tinggal di Kota Semarang. Namun 100\% masyarakat Kota Demak menyatakan bahwa frekuensi dalam mengunjungi teman/ rekan yang tinggal di Kota Semarang dalam kondisi yang tidak pasti, tidak dapat ditentukan karena berlangsung secara spontan dan tanpa dijadwalkan dalam setiap bulannya.

Organisasi sosial yang diikuti oleh para komuter tersebut cenderung sedikit, karena mereka telah disibukkan oleh jadwal pulang dan pergi untyuk menuju Kota Semarang setiap harinya. Meskipun demikian, 13\% responden tergabung ke dalam organiasasi sosial di Kota Demak. Bentuk organisasi tersebut pun disesuaikan dengan profesi responden. Sementara itu yang tergabung ke dalam organisasi sosial yang terletak di Kota Semarang hanya 9\%. Rendahnya keikutsertaan masyarakat dalam organisasi sosial disebabkan oleh kesibukannya dalam beraktivitas sehari-hari. Jadi secara keseluruhan keterkaitan sosial dari Kota Demak terhadap Kota Semarang ditunjukkan oleh Gambar 5.

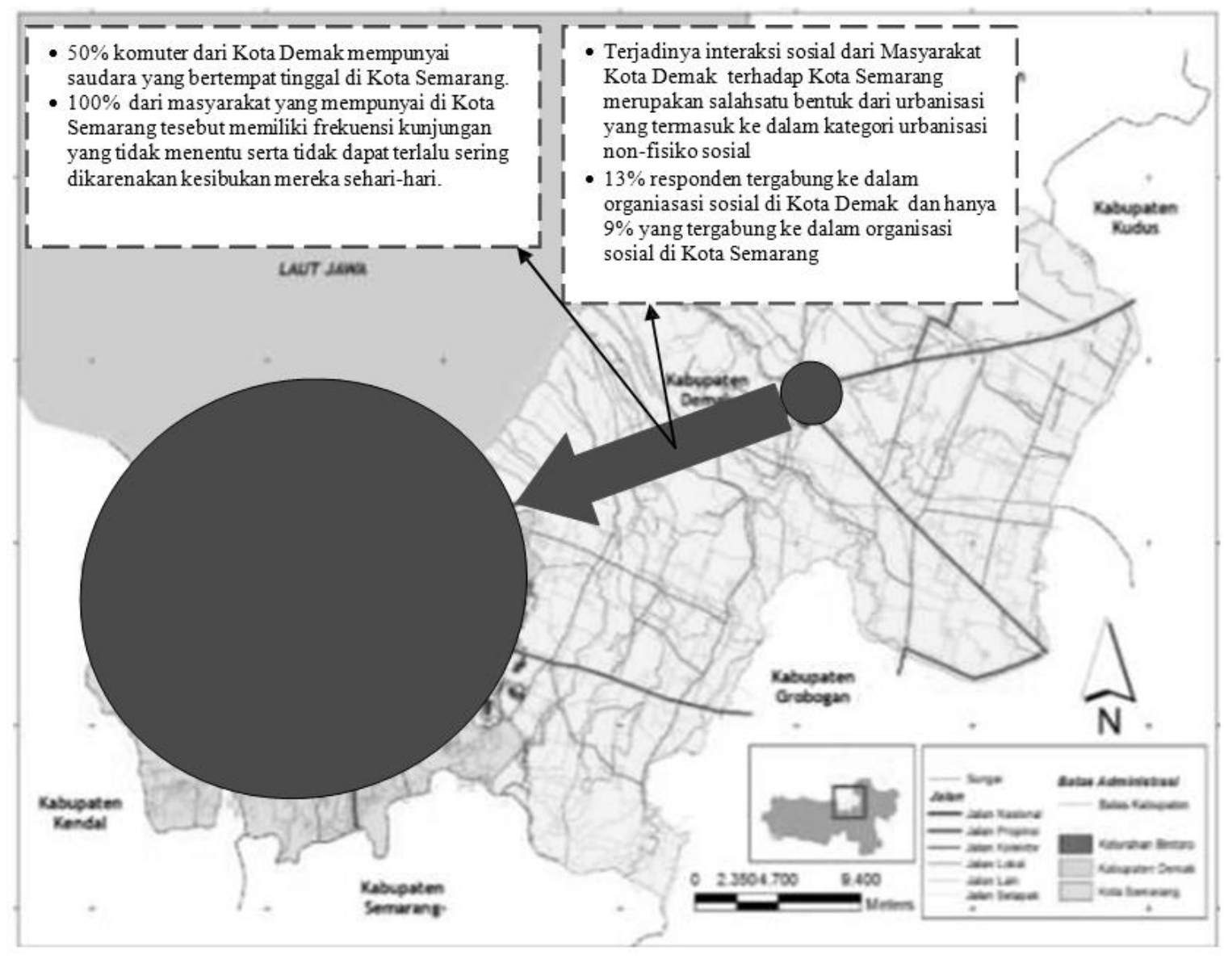

Gambar 5. Keterkaitan Sosial Kota Demak terhadap Kota Semarang 


\section{Kesimpulan dan Rekomendasi}

Bentuk hubungan keterkaitan dari Kota Demak terhadap Kota Semarang dapat dilihat berdasarkan kondisi fisik dan kegiatan masyarakat baik dari segi ekonomi maupun sosial. Adapun dalam penelitian ini wujud dari bentuk interaksi difokuskan pada kondisi fisik, ekonomi dan sosial. Bentuk keterkaitan fisik direpresentasikan dari keterkaitan fisik, sedangkan representasi dari bentuk kegiatan yaitu dari keterkaitan ekonomi dan sosial. Wujud dari hubungan yang terjadi dari Kota Demak terhadap Kota Semarang yaitu adanya masyarakat dari Kota Demak yang melakukan pergerakan secara ulang-alik, dalam pengertian pergerakan dari Kota Demak ke Kota Semarang yang rutin dilakukan hampir setiap hari. Hal tersebut sesuai pernyataan dari Adisasmita (2006: 150) bahwa wujud dari hubungan atau interaksi yang terjadi antarkota atau antarwilayah dapat diwujudkan melalui urbanisasi, ruralisasi, sirkulasi serta ulang-alik/ commuting.

Bentuk interaksi fisik dari Kota Demak terhadap Kota Semarang membentuk suatu hubungan ketergantungan, karena keberadaan Kota Semarang sangat mempengaruhi dalam bidang transportasi, mengingat kedua kota tersebut dihubungkan oleh jalan yang merupakan jalur utama untuk pergerakan regional Jawa Tengah. Jika kondisi fisik Kota Semarang tidak memungkinkan untuk dilalui maka tidak dapat terjadi pergerakan dari Kota Demak. Berdasarkan kondisi fisik di Kota Demak, terjadi gejala urbanisasi fisiko-spasial yang terjadi di Kota Demak dari segi karakteristik penggunaan lahan, terutama karena dilatarbelakangi oleh perkembangan dalam bidang transportasi internal yang juga merupakan simpul transportasi utama yang terdapat di Jawa Tengah sekaligus jalan tersebut sejalur dari jalan utama di Kota Semarang yang terklasifikasi dalam Jalur Pantai Utara Jawa. Kondisi jalan utama yang menghubungkan Kota Demak dan Kota Semarang beraspal dan merupakan kelas jalan arteri primer menyebabkan kemudahan hubungan dari segi transportasi. Ketersediaan sarana dan prasarana transportasi yang menghubungkan Kota Demak dan Kota Semarang dilihat dari indikator moda transportasi dan kendaraan umum, dengan indikator waktu tempuh, biaya transportasi dan hambatan yang dirasakan oleh para komuter untuk menuju Kota Semarang.

Rustiadi (2009: 323) mengemukakan bahwa kemudahan hubungan fisik pada sektor transportasi akan meningkatkan intensitas hubungan antarwilayah. Demikian halnya yang terjadi di Kota Demak. Untuk aspek biaya tempuh sebagian besar tidak merasa bermasalah karena untuk sekali perjalanan dengan menggunakan bus hanya membutuhkan ongkos Rp 2.000,- untuk pelajar dan pekerja industri dan Rp 3.000,- untuk umum. Kemudahan fisik yang dimaksud terdiri atas kondisi jalan beraspal dan tidak terdapat kerusakan parah serta ketersediaan angkutan umum utama berupa bus dengan feeder di Kota Demak berupa bus, ojek, becak dan angkot. Hasil temuan studi menemukan kesimpulan bahwa penglaju dari Kota Demak ke Kota Semarang cenderung menggunakan kendaraan pribadi berupa sepeda motor karena paling efisien dari segi waktu tempuh, biaya transportasi dan hambatan. Hambatan yang paling sering dirasakan oleh para penglaju tersebut yaitu cuaca yang panas pada koridor jalan utama Demak-Semarang serta sulitnya memperoleh angkutan umum karena jadwal kedatangan kendaraan yang tidak pasti. Setelah melalui proses uji crosstab, hal yang paling berpengaruh terhadap tingkat hambatan aksesibilitas penduduk Demak untuk menuju Kota semarang adalah faktor waktu tempuh.

Bentuk interaksi ekonomi dari Kota Demak terhadap Kota Semarang adalah ketergantungan, karena hanya terjadi satu arah dari Kota Demak terhadap Kota Semarang. Dalam bidang ekonomi khususnya berkaitan dengan fasilitas perkotaan, penduduk Kota Demak melakukan pergerakan ke Kota Semarang untuk mengakses fasilitas perkotaan yang memang tidak tersedia di Kota Demak, sehingga dalam bidang fasilitas perkotaan Kota Demak masih tergantung kepada Kota Semarang. Hal ini terbukti berdasarkan hasil kuesioner bahwa sebanyak 99,9\% responden merasa Kota Demak masih mempunyai 
kekurangan fasilitas mulai dari fasilitas perekonomian, kesehatan, pendidikan dan rekreasi dan $86 \%$ dari mereka selalu melakukan transaksi pembelian barang di Kota Semarang.

Keterkaitan ekonomi yang merupakan bentuk interaksi dari kegiatan berupa upaya masyarakat Kota Demak menuju Kota Semarang dalam rangka memenuhi kebutuhannya, dikarenakan perbedaan sumber daya yang dimiliki oleh Kota Demak dan Kota Semarang. Kebutuhan tersebut diwujudkan dalam bentuk lapangan pekerjaan, pemilihan lokasi belanja dan akses terhadap fasilitas perkotaan. Hal tersebut terjadi akibat Kota Semarang mempunyai kelengkapan yang sangat tinggi di bidang tersebut dan hal-hal tersebut tidak tersedia di Kota Demak.

Bentuk interaksi sosial dari Kota Demak terhadap Kota Semarang keterkaitan, yaitu hubungan yang tidak tergantung, penduduk Kota Semarang mempengaruhi penduduk Kota Demak dalam terjadinya keterkaitan sosial. Keterkaitan sosial terjadi sebagai dampak dari terjadinya keterkaitan ekonomi yang dilakukan oleh Masyarakat Kota Demak terhadap masyarakat di Kota Semarang. Keterkaitan sosial dilihat dari segi hubungan kekeluargaan, kekerabatan dan organisasi sosial yang mendorong terjadinya kunjungan sehingga terjadi pergerakan penduduk dari Kota Demak menuju Kota Semarang. Kunjungan saudara dan kekerabatan tidak dilakukan secara teratur karena jadwal kegiatan yang tidak dapat dipastikan sehingga frekuensi kunjungan tidak menentu.

Faktor yang mempengaruhi terjadinya hubungan interaksi tersebut yaitu karena kedudukan Kota Semarang sebagai kota induk dan Kota Demak adalah kota satelitnya sebagai suatu kesatuan dalam wilayah metropolitan. Selain itu orde Kota Semarang pun jauh lebih tinggi dibandingkan dengan orde Kota Demak sebagaimana yang tercantum dalam dokumen RTRW Provinsi Jawa Tengah bahwa Kota Semarang adalah kota orde I sebagai pusat pertumbuhan dan pusat pelayanan di tingkat provinsi sedangkan Kota Demak merupakan kota orde II sebagai pusat pelayanan sub-wilayah.

Interaksi yang terjadi dari Kota Demak dan Kota Semarang mendorong adanya tindak lanjut dalam proses perencanaan wilayah dan kota agar perkembangan Kota Demak sesuai dengan yang telah direncanakan sebelumnya. Kecenderungan masyarakat Demak untuk mengakses berbagai kebutuhan dan fasilitas perkotaan di Kota Semarang dapat menimbulkan kesenjangan kemajuan perkotaan. Adapun penjabaran rekomendasi tersebut adalah sebagai berikut:

- Pemerintah Kota Demak sudah selayaknya menyediakan fasilitas perekonomian berupa pusat perdagangan yang lebih lengkap supaya hubungan ketergantungan terhadap kota induk tidak terlalu tinggi mengingat Kota Semarang tidak hanya sebagai kota induk bagi Kota Demak karena masih banyak kota satelit lainnya di sekitar Kota Semarang.

- Selain fasiilitas perekonomian, fasilitas kesehatan yang ada di Kota Demak pun harus ditingkatkan kualitas atau mutu pelayanannya supaya setiap masyarakat Kota Demak tidak selalu tersugesti untuk berobat ke Kota Semarang.

- Perlu dilakukannya pemeliharaan kondisi jalan utama yang menghubungkan Kota Demak dan Kota Semarang demi terjadinya kelancaran arus lalu lintas yang melaluinya karena jalan tersebut juga melayani pergerakan utama di Pulau Jawa terutama di Provinsi Jawa Tengah.

\section{Ucapan Terima Kasih}

Terimakasih kepada Bp. Ir. Jawoto Sih Setyono, MDP selaku pembimbing penelitian ini serta kepada responden yang telah bersedia menjadi sumber informasi. 


\section{Keterkaitan Kota Demak terhadap Kota Semarang dalam Lingkup Wilayah Metropolitan}

\section{Daftar Pustaka}

Adisasmita, Rahardjo. 2006. Pembangunan Kelautan dan Kewilayahan. Yogyakarta: Graha Ilmu

Andini, Isti. 2006. "Sistem Perkotaan Pada Koridor Semarang-Surakarta." Tugas Akhir tidak diterbitkan, Program Studi Perencanaan Wilayah dan Kota, Fakultas Teknik Universitas Diponegoro, Semarang.

Aprilian, Iin. 2010. Interaksi Desa dan Kota. [Home page Sebening Embun Pagi] [Online]. Available at http://iinaprilian.wordpress.com/2010/12/22/interaksi-desa-dan-kota/teraksi-desa-dan-kota/. Diakses pada tanggal 20 April 2011.

Basuki, Yudi. 2008. Pedoman Metode Analisis Perencanaan Wilayah dan Kota. Diktat Kuliah. Semarang : Fakultas Teknik UNDIP

Bintarto, R. 1983. Interaksi Desa-Kota dan Permasalahannya. Yogyakarta: Ghalia. Pelajar.

Choguill, Charles L. 2005. "The Research design Matrix: A Tool For Development Planning Research Studies. "Habitat International 29 (2005) 615-626.

Direktorat Jenderal Penataan Ruang. 2006. Berita Penataan Ruang. [Home page Departemen Pekerjaan Umum ] [online]. Available at: www.penataanruang.net/taru/upload/berita_ cetak/beritaPR2.pdf. Diakses pada tanggal 20 April 2011.

Leedy, Paul D. 1997. Practical Research : Planning and Design, sixth edition. Prentice-Hall., Inc: New Joursey

Kecamatan Demak Dalam Angka 2008. Badan Pusat Statistik, 2010.

Direktur Jendral Penataan Ruang dkk, 2009. "Kebijakan pengembangan kawasan terkait Trans Asia dan Asean Highways." Makalah disampaikan pada Seminar Nasional dalam Konteks Trans Asia dan Asean Higways dan tantangan menghadapi tatanan global yang diselenggarakan oleh BALITBANG DEPT. PU - DITJEN BINA MARGA - HPJI. Jakarta. 1 Juli 2009.

Kota Semarang Dalam Angka 2009. Badan Pusat Statistik, 2010.

Martono, Primasto Ardi. 2008. "Keterkaitan Antar Sektor Ekonomi dan Antar Daerah Di Wilayah Kedungsepur". Tesis tidak diterbitkan, Program Studi Pengembangan Wilayah dan Kota, Fakultas Teknik Universitas Diponegoro, Semarang.

Menteri Pekerjaan Umum Republik Indonesia. 2006. "Penjelasan Menteri Pekerjaan Umum mengenai Rencana Tata Ruang Kawasan Jabodetabek-Punjur sebagai masukan untuk RUU Pemerintahan Provinsi Daerah Khusus Ibukota Negara Republik Indonesia.” Jakarta.

Nazir, Moh. 2006. Metode Penelitian. Ghalia Indonesia: Jakarta.

Nugroho, Prihadi. 1997. "Karakteristik Kota-Kota Kedua di Provinsi Jawa Tengah." Tugas Akhir tidak diterbitkan, Program Studi Perencanaan Wilayah dan Kota, Fakultas Teknik Universitas Diponegoro, Semarang.

Nurhadi, Moh. 2000. "Peran Commuter terhadap Pembangunan Wilayah di Kecamatan Sayung Kabupaten Demak." Tugas Akhir tidak diterbitkan, Program Studi Perencanaan Wilayah dan Kota, Fakultas Teknik Universitas Diponegoro, Semarang.

Rencana Detail Tata Ruang Kota Kecamatan Demak Tahun 2008 - 2028. Badan Perencanaan Pembangunan Daerah Kabupaten Demak, 2010.

Rencana Tata Ruang Wilayah Provinsi Jawa Tengah Tahun 2010 - 2030. Badan Perencanaan Pembangunan Daerah Jawa Tengah, 2009.

Ridho, Muhammad. 1998. "Studi Penentuan Pusat- Pusat Pelayanan Wilayah di Kabupaten Dati II Demak. Teknik Perencanaan." Tugas Akhir tidak diterbitkan, Program Studi Perencanaan Wilayah dan Kota, Fakultas Teknik Universitas Diponegoro, Semarang.

Rustiadi, Ernan dkk. 2009. Perencanaan dan Pengembangan Wilayah. Yayasan Obor Indonesia: Jakarta.

Rondinelli. 1985. Applied Methods of Regional Analysis. Praeger Publisher: United States of America.

Sabari Yunus, Hadi. 2006. MEGAPOLITAN Konsep, Problematika dan Prospek. Pustaka Pelajar: Jogjakarta.

2010. Metodologi Penelitian Wilayah Kontemporer. Pustaka Pelajar: Jogjakarta. 
Stephen M. Wheeler. 2000. Planning for Metropolitan Sustainability, Journal of Planning Education and Research 2000; 20; 133

Studi Manajemen Transportasi Kabupaten Demak, 2006. Badan Perencanaan Pembangunan Daerah Kabupaten Demak, 2010.

Sugiyono. 2009. Memahami Penelitian Kualitatif. Bandung: Alfabeta.

Suprapta, 2003. “Ketergantungan Wilayah Kecamatan Mranggen terhadap Kota Semarang." Tesis tidak diterbitkan, Program Studi Perencanaan Wilayah dan Kota, Fakultas Teknik Universitas Diponegoro, Semarang.

Winarsi, Haryo dan Delik Hudalah (eds.). 2006. “Metropolitan di Indonesia, Kenyataan dan Tantangan” Dalam Penataan Ruang. Jakarta.

Widodo, Satriyo Catur. 2003. "Interaksi Kecamatan di Wilayah Pinggiran Metropolitan dengan Kota Induknya.” Tesis tidak diterbitkan, Program Studi Pengembangan Wilayah dan Kota, Fakultas Teknik Universitas Diponegoro, Semarang.

Wiratmaja, Ida Bagus. 2002. “Aspek Budaya Masyarakat Bali Dalam Fenomena Suburbanisasidi Kawasan Sarbagita." Tesis tidak diterbitkan, Program Studi. Pengembangan Wilayah dan Kota, Fakultas Teknik Universitas Diponegoro, Semarang. 
122 Keterkaitan Kota Demak terhadap Kota Semarang dalam Lingkup Wilayah Metropolitan

JURNAL WILAYAH DAN LINGKUNGAN, 1 (2), 105-122 